\title{
Employment Models of Platform Companies in Norway: A Distinctive Approach?!
}

\section{Kristin Jesnes ${ }^{2}$}

Researcher, Fafo, Institute for Labour and Social Research, Norway

\begin{abstract}
The past decade has seen an increase in 'platform companies' functioning as the intermediary between workers and customers. The way these companies structure the labour process has significant implications for working conditions. In this article, we ask: In what ways does platform work in Nonway differ from standard employment relationships? And do different employment strategies of platform companies put workers in precarious situations? The article builds on qualitative interviews with CEOs of platform companies in Norway, and aims to contribute to the literature by formulating a typology of the employment models of platform companies emerging in the Nordic countries. The platforms' employment models are compared to the standard employment relationship and precariousness. Finally, the article suggests that institutions matter for why some platform companies adopt elements of the standard employment relationships as they appear in the Nordic labour market models, and discusses the implications of this.
\end{abstract}

\section{KEYWORDS}

flexibility / nonstandard employment / Nordic labour market model / platform companies / platform work / precarization / working conditions

\section{Introduction}

typical and precarious work have been uppermost on the research agenda in recent years. Together with new technology and new forms of work, platform companies have revived a debate about the future of work and the standard employment relationship (SER). In contrast to companies offering open-ended full-time contracts, platform companies give rise to pure market relationships where labour is treated more like a commodity (Rubery et al. 2018). Platform companies rely on self-employed individuals as a workforce, and the companies provide an infrastructure for mediating services between customers and workers, reducing transaction costs by outsourcing everything from equipment to workforce (Srnicek 2017). Uber is the ideal example - a transportation company that owns no cars and has no employees. Upwork is another example of a company that outsources small office-based tasks to a crowd of workers. Srnicek (2017) claims this development to be a return to the 'piecework' of early industrial capitalism, while De Stefano (2016) refers to it as a 'just in time workforce' and 'commodification of labour'.

The term 'platform worker' is used to refer to those working via platform companies, regardless of their contractual relations. This has also been called crowdwork (De

\footnotetext{
${ }^{1}$ You can find this text and its DOI at https://tidsskrift.dk/njwls/index.

${ }^{2}$ Corresponding author: Kristin Jesnes, Researcher, Fafo. E-mail: krj@fafo.no.
} 
Stefano 2016) and gig work (Wood et al. 2018). To date, there is no legal definition of platform work, but the phenomenon shares similarities with atypical work, such as on-call, zero-hour contracts or temporary agency work. Similar to temporary agency work, platform work constitutes a triangular relationship between a platform, a provider of labour and a customer, either an individual or a company, which blurs the rights and responsibilities in the employment relationship (Dølvik \& Jesnes 2017). Stewart and Stanford (2017) outline four characteristics of platform work: (1) varying working hours and work periods, (2) no furnishing of equipment needed to carry out the job, (3) no workplace provided by the company and (4) mediation of tasks by means of digital technology (i.e. apps or software). These characteristics suggest that platform work is a new form of atypical work. So far, no widespread agreement exists on whether this new form of work represents a possibility for earning occasional income with flexibility and freedom for the worker, or if it leads to poor working conditions and a more permanent precarious position in the labour market (Rubery et al. 2018). This might also depend on the workers' skill level and labour market opportunities, and on the institutional context with regard to both country-specific industrial relations regimes (Visser 2009) and type of industry in which the platform company operates (Bechter et al. 2012).

In the Nordic countries, platform companies are likely to experience pressure from highly organized labour markets, which might limit their spread or change how such companies develop (Dølvik \& Jesnes 2017). This makes the emergence of platform companies in Nordic countries particularly interesting to study. The Nordic labour market models are characterized by low unemployment, an advanced welfare state modelled around the binary relationship between employer and employee, strong social partners and a centralized collective bargaining system that plays a critical role in regulating wages and working conditions (Andersen et al. 2014). Norway, which is the case country in this article, stands out in a Nordic context with somewhat lower levels of trade union density and collective bargaining coverage compared to the other Nordic countries, but these are still high in a European context. The platform companies also operate in industries with low union density or where self-employment is more common, and where it might be easier to exploit workers and more difficult to negotiate collective agreements (Alsos et al. 2017). Such 'cracks' in the Nordic labour market model might make platform work detrimental for some already highly pressured industries such as cleaning and transportation (Alsos \& Trygstad 2018; Hotvedt 2019).

While platform work is considered to be on the rise internationally (Kässi \& Lehdonvirta 2016), it remains marginal in the Nordic countries. Research suggests that between $0.3 \%$ and $2.5 \%$ of the working age population in the Nordic countries have worked through a platform during the past year (Alsos et al. 2017; Ilsøe \& Madsen 2017; Official Statistics of Finland, 2017; SOU 2017:24). In the UK, a more liberalized environment, Pesole et al. (2018) suggest that $4 \%$ of the adult population receive $50 \%$ or more of their monthly income through platforms (p. 19). Together with a rise in zerohour contracts, platform work and solo self-employment might contribute to processes of normalization of precarious work in Europe (Rubery \& Grimshaw 2016). These groups, often overlapping, are at a higher risk of in-work poverty (Eurofound 2017). All of this makes the emergence of platform companies in a Nordic context a highly topical and important issue to study.

This article explores employment models of platform companies in Norway, with the aim of providing a typology of the platform companies emerging in a Nordic context, 
and assessing the extent to which the employment strategies of platform companies put workers in a precarious situation. The research questions are as follows: In what ways does platform work in Norway differ from SERs? And do different employment strategies of platform companies put workers in precarious situations? Building on qualitative interviews with CEOs and other managers of 10 platform companies in Norway, the article will examine the employment models of platform companies from the CEO/ employer perspective. There are good arguments for interviewing CEOs about their business models. First, it is important to explore how platform companies organize and distribute work in order to understand the working conditions for platform workers and how these differ from SERs. Second, while the business models of some large international companies are known and researched (see for instance Berg 2016; Wood et al. 2018), there is a dearth of knowledge on Nordic platforms and on how international companies operate in different national contexts. Third, interviews with CEOs/employers might reveal how they relate to the institutional context and the reasons behind their choice of employment model.

The article is organized as follows: First, I explore existing research and theories on platform companies, the SER and employer strategies. Second, I outline the data and methods on which the article builds. Third, I explore the employment models of the platforms with two case studies. Based on this, I introduce a typology of different platforms emerging in the Nordic countries, and suggest a few possible explanations for why companies mediate work the way they do, as well as some of the implications of these models for working conditions. Finally, I summarize the findings and suggest further research.

\section{Background and analytical framework}

There is a vast amount of literature on the SER, atypical work and precarious working conditions. The literature covering platform work is also growing. The analytical framework of this article draws on selected literature from the following research areas: (1) platform companies and challenges to the employment relationship, (2) commodification of the SER and (3) employer strategies and the institutional context.

\section{Platform companies and challenges to the standard employment relationship}

Literature on platform work describes many differences between platform companies, and platform work includes a wide range of tasks and occupations. Foodora, a German food-delivery company, is an example of low-skilled work mediated through platforms. Upwork is an example of a company mediating medium- to high-skilled office-based tasks to a crowd of workers internationally. Howcroft and Bergvall-Kåreborn (2018) make a distinction between 'online task crowdwork', like that provided by Upwork, and 'asset-based services', like those provided by Uber and Foodora where the drivers and couriers use their own cars or bikes for transportation. Within this distinction, there are also differences between services provided in local labour markets and those provided online (Codagnone et al. 2016). Pongratz (2018) refers to services delivered physically 
in a local labour market as 'mobile labour', whilst services delivered online are referred to as 'online labour'. De Stefano (2016) addresses this difference using the terms 'workon-demand via apps' and 'crowdwork'. 'Crowdwork' refers to work mediated through online platforms, while 'work-on-demand via apps' refers to traditional work activities, such as transport and cleaning. The distinction between crowdwork and work ondemand is not always clear, as crowdwork is also delivered on demand, and on-demand services are dependent on a crowd of workers (Alsos et al. 2017). In this article, the terms 'online' and 'local' are used to highlight where the service is delivered.

One commonality across the different types of platform companies is that they often rely on solo self-employed as a workforce, rather than on employees (Berg 2016). Solo self-employed are self-employed without own employees. Although few would regard a self-employed person with high skills and a stable high income as precarious, this is not necessarily the situation for all platform workers. Most platform workers in the Nordic countries are young, low-paid, male and often with an ethnic minority background. The platform work that they perform most commonly requires low skills and often serves as an occasional source of income (Ilsøe \& Madsen 2017). Oppegaard (2018) finds that Uber Black drivers in Oslo are immigrants with few prospects of finding another job and that they are subject to Uber's algorithmic control and rely on the income from Uber for a living. This indicates that labour market insiders are not necessarily those that perform platform work in the Nordic countries (Dølvik \& Jesnes 2017).

Although the platform companies designate their workers as self-employed, this is not necessarily the case from a legal point of view (Hotvedt 2019). Platform workers might appear as self-employed in labour statistics and consider themselves as selfemployed, but still, in legal terms, be employees (Ibid.). If there are disagreements about their contractual status, workers can take their case to court. In such a case, the court can perform its own assessment of the realities in the relationship, referred to as 'the contract-of-employment test' (Hotvedt 2018a). The Supreme Court of Norway has previously assessed ambiguous contract relationships, and the key elements that establish employer responsibility in these cases are the performance of personal continuous work under supervision and control, and in exchange for remuneration (Hotvedt 2018b).

One strand of research describes how platform companies extensively control work processes through tools such as algorithms and rating systems, and that legal assessments should take this into consideration (Hotvedt 2016, 2018a; Prassl 2018). Platform companies use data from user registration, ratings and GPS in algorithms that manage work processes and job distribution, termed 'algorithmic management' (Lee et al. 2015). With the use of algorithms and apps in the distribution of platform work, Hotvedt (2018a) argues for a careful renewal of the contract-of-employment test. This implies that the court should also take account of the business model, and not only the individual workers' dependence on the company. Elements such as control of work performance through customer ratings and platform involvement in the service would be central elements in such an assessment (Ibid.).

In the Nordic countries, there are currently no legal proceedings concerning platform workers. The outcome of such legal assessments might also vary from one legal regime to another and from platform to platform, which is exemplified by two court cases from the UK: while food-couriers in Deliveroo were considered self-employed by the Central Arbitration Committee, two Uber drivers were considered workers by the London Employment Tribunal (2016). The category of 'workers' in British labour law

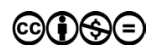


falls between that of self-employed and employees, giving access to some but not all employee rights, including paid rest, vacation and minimum pay. The different courts emphasized different elements of the relationship. In Aslam and Farrar $v$ Uber, the issue of control and supervision by the company was central. In the Deliveroo case, the couriers were considered self-employed because someone else could substitute for a courier by taking an assignment. Consequently, collective bargaining rights were denied (Moore \& Newsome 2018).

\section{Commodification of the standard employment relationship}

According to Rubery et al. (2018), the essence of the SER is its substantive protections against a pure market relationship where labour is treated as a 'disposable commodity to be bought and sold' (p. 1). This includes guaranteed wage income, adequate pay, stability of employment, fair dismissal procedures, division between work and nonwork periods, competence development, adjustments to the needs of individuals (such as illness and parental leave), opportunities for workers to voice their opinions and requests, and access to social security benefits (Rubery \& Grimshaw 2016). In contrast to SERs, precarious work is associated with insufficient and variable hours, low pay and limited labour and social protection rights. These are characteristics often found in atypical forms of work such as zero-hour contracts, part-time and temporary work, and solo self-employment and platform work (Rubery et al. 2018). The mentioned categories also often overlap.

In the study by Rubery et al. (2018), dimensions of decommodification are developed into the SOFL framework, which describes the idealized SER, and includes the following dimensions: (1) security of income, (2) access to opportunity through competence development, (3) fair treatment through the institutional embedding of employment rights and voice mechanisms, and (4) recognition of life beyond work through regular hours and a clear division between work and nonwork time. Without these dimensions, outlined in Table 1, there is a risk of workers being exposed to poor working conditions and a more permanent precarious position in the labour market.

Table I The SOFL framework, simplified version of Rubery et al. (2018:5/4)

\begin{tabular}{lll}
\hline SOFL & SER & Precarious work gaps \\
\hline Security & $\begin{array}{l}\text { Adequate income during work } \\
\text { and nonwork periods }\end{array}$ & $\begin{array}{l}\text { Limited access to guaranteed wage income and social } \\
\text { protection }\end{array}$ \\
\hline Opportunity & $\begin{array}{l}\text { Platform for investment in } \\
\text { training and career }\end{array}$ & $\begin{array}{l}\text { Exclusion from the SER due to nonstandard life course } \\
\text { Poor training/career opportunities }\end{array}$ \\
\hline Fair treatment & $\begin{array}{l}\text { Institutional framework for } \\
\text { rights and voice at work }\end{array}$ & $\begin{array}{l}\text { Exclusion from institutional framework due to contract } \\
\text { form/subcontracting }\end{array}$ \\
\hline Life beyond & Division between work and & Exclusion from the SER due to nonwork commitments. \\
work & nonwork time & Subject to employer flexibility demands. \\
\hline
\end{tabular}

The employment relationship protects the worker, the weaker party in the relationship, and the possible consequences for workers lacking the standards provided by the employment relationship are many. Rubery and Grimshaw (2016) emphasize the risk 
of income insecurity and the pressure it places on living standards. Without guaranteed income, it is more difficult to plan or obtain credit and housing, and sick leave, vacation or parental leave are likely to be cut. Without access to competence building, workers may not be able to progress in their work, maintain their position or have access to other job opportunities. The division between work and nonwork periods is blurred by the constant search for new jobs. Moreover, the fear of loss of employment or hours may create a psychologically difficult situation. Institutional systems ensure fair treatment, and without them, workers may fear making complaints, as this might lead to a loss of work. In addition, regulations on social security may lead to exclusion from social protection offered by the welfare state. Rubery et al. (2018) refer to these elements as 'precarious work gaps' (see Table 1).

Alberti et al. (2018) emphasize how managers drive precarization by imposing particular contracts on workers, and suggest that this might be the case with zero-hour contracts, temporary agency work or platform work. Platform companies often designate their workforce as self-employed regardless of the amount of control they exert over the working conditions and pay levels (Berg 2016). Moore and Newsome (2018) describe the choice to rely on a workforce of self-employed as a transfer of 'risk and the social costs of employment (sick pay, vacation pay and pensions) to the worker' (p. 478). Contractual arrangements not only determine access to individual labour rights and social security, but also to collective labour rights such as the right to collective bargaining and the right to strike (De Stefano \& Aloisi 2018).

In the Nordic countries, labour rights and the advanced welfare system are modelled around the binary relationship between an employer and an employee, whereas the self-employed (a nonemployee who receives salary) are not covered by the Working Environment Act, which covers most working life issues. Table 2 gives an overview of the rights and benefits of employees, freelancers and self-employed in Norway. The table summarizes how self-employed persons carry the risks associated with the business, and thus do not have the same rights and benefits as employees, for instance with regard to sick leave, parental leave or paid vacation. Also, in industries where collective agreements are extended to cover all workers, such as in the cleaning industry and hotels and restaurants in Norway, the self-employed are not covered. Freelancers have somewhat wider access to social security than self-employed (Nergaard \& Øistad 2016).

Table 2 Rights and benefits for employees, freelancers and self-employed in Norway, Altinn 2019

\begin{tabular}{llll}
\hline Rights and benefits & Employee & Freelancer & Self-employed \\
\hline Sick pay & $\begin{array}{l}\text { I00\% from } \\
\text { first day }\end{array}$ & $\begin{array}{l}\text { I00\% after I6 days, may have } \\
\text { insurance }\end{array}$ & $\begin{array}{l}\text { 75\% after I6 days, may have } \\
\text { insurance }\end{array}$ \\
\hline Occupational pension & Yes & No & No \\
\hline Unemployment benefits & Yes & Yes, as employees & No, may sign up for insurance \\
\hline Injury benefits & Yes & No, may sign up for insurance & No, may sign up for insurance \\
\hline $\begin{array}{l}\text { Covered by the Working } \\
\text { Environment Act }\end{array}$ & Yes & Depends on the situation & No (with the exception of \\
& & & $\begin{array}{l}\text { provisions on discrimination } \\
\text { and health and safety) }\end{array}$ \\
\hline $\begin{array}{l}\text { Collective rights (strike, } \\
\text { collective bargaining) }\end{array}$ & Yes & Depends on the situation & No, due to competition law \\
\hline
\end{tabular}




\section{Employer strategies and the institutional context}

From an employer perspective, the need for flexibility in the workforce is central. Some of the earliest work on flexibility was Atkinson's model of the flexible firm (1984). The model implies that all companies combine numerical and functional flexibility. Functional flexibility refers to the situation in which one worker can perform many different tasks in the company, and becomes part of its core workforce. These workers are usually permanent employees and receive more training. Numerical flexibility implies that the company increases or decreases its workforce according to demand. This creates a peripheral workforce with atypical forms of employment and with less training (Atkinson 1984). According to Srnicek (2017), platform companies are hyper-outsourced business models - in which numerical flexibility seems to be essential. Svalund et al. (2018) find that companies in Sweden and Norway use a combination of atypical forms of employment in their search for a flexible workforce. Platform work might be a new addition to the menu of atypical forms of employment used by companies.

The literature addressing employment relations suggest several explanations to why companies operate differently in diverse institutional contexts. One explanation is that the organization of work and form of employment used by a company depend on the institutional context and how employment relationships are regulated nationally (Visser 2009). Bechter et al. (2012) point out that industry-specific traits might be more relevant than country-specific traits with regard to regulating employment relationships. As mentioned earlier, this is in line with the findings of Alsos et al. (2017) showing that platform companies usually operate in industries with low union density or where self-employment is more common, probably to avoid pressure from trade unions and other actors, and because in these industries, it is easier to find regulatory loopholes and thereby expand. Rasmussen (2018) also suggests that it is easier to regulate platforms that mediate work locally rather than online, as well as platforms that fit into existing industry profiles. One avenue of research also discusses the country-of-origin effect (Ferner 1997), whereby a company's country of origin plays a role in the way work is organized in that company, no matter what country it operates in. Alsos and Trygstad (2018), on the other hand, found that foreign-owned companies are better at following statutory regulations than Norwegian companies, as they try to appear responsible.

There are two particularities of platform companies in the Nordic countries, which suggest a distinctive approach to employment models. The first particularity is that some of the approximately 30 platforms mediating labour in Norway consider their workers as employees and not self-employed (Alsos et al. 2017). Some of the platform workers have marginal part-time contracts, that is less than 15 hours per week. Ilsøe et al. (2017) argue that marginal part-time contracts might be associated with very low annual income and hence precarious work, and according to Eurofound (2017), involuntary part-timers are most at risk of in-work poverty. Hence, this new model of employment is far from the norm of open-ended full-time contracts. The second particularity is the emerging collective agreements with trade unions (Jesnes et al. 2019; Munkholm \& Schjøler 2018). Examples of this are the collective agreements between the cleaning platform company Hilfr and 3F in Denmark, the moped transport company Bzzt and the Swedish Transport Workers Union, and the ongoing negotiations for a collective agreement between Foodora and the Norwegian Transport Workers Union. All of these platforms mediate low-skilled work. However, the white-collar trade union Unionen 
also has agreements with Instajobs and Gigstr, whereby the workers are covered by regulations for temporary agency workers (Jesnes et al. 2019). These two particularities might suggest that platform companies in the Nordic countries have a distinctive approach to employment models.

In sum, there is much research describing challenges to the SER but less on how platform work emerging in the Nordic countries differs from the SER, why platform companies mediate work the way they do and what consequences this might have for platform workers in a Nordic setting.

\section{Data and methods}

Qualitative interviews with CEOs and managers of platform companies provide an important insight into how these organizations set the framework for working conditions for their platform workers. For instance, when a CEO states that the company does not take health and safety into consideration because the company is a 'marketplace' instead of an employer, this implies significant consequences for the working conditions provided. Interviews with CEOs also offer insight into reasons behind the choice of employment model. Moreover, the Norwegian context allows us to explore more local platforms, as well as how international companies operate in a particular national context.

The article builds on interviews with 10 CEOs and managers of platform companies that mediate work in Norway (Alsos et al. 2017). The selection was based on theoretical sampling whereby variation in the activity exercised by the platform companies was important, as were variations concerning origins of the company, skill-level required for the tasks mediated and the location of the services (local or online). The final sample of companies was also determined by access. One limitation of the study is that only two labour platforms mediating high-skilled work are included, and therefore an in-depth analysis of the variation between platforms mediating low-skilled and high-skilled tasks was not possible.

In the final sample (see Table 3), six of the 10 companies have platform workers located both in Norway and abroad, and some of the companies have a Nordic profile. Two of the 10 companies mediate services online, while one mediates services both online and in local labour markets. The companies have both individuals and businesses as customers. Most of them operate in the Oslo region or in other large Norwegian cities. Five of the platforms are registered as companies running web portals or programming services, while the others are registered in more traditional industries, including cleaning, transport and manual work. Most of them started their business in Norway after 2014 and are newcomers in a Nordic context.

The interviews were conducted between September 2016 and October 2017. The informants were either the CEO or other managers of the platform companies, and the interviews lasted from 30 to 90 minutes. Eight interviews were face-to-face, and two were by phone or via online webcam. The companies were promised anonymity. The interviews were semi-structured, which ensured that the various topics in the interview guide were addressed in all the interviews, while at the same time providing the opportunity to discuss topics in more depth. The interview guide was developed with inspiration from the preparatory work to the Working Environment Act on the employment relationship (Ot.prp nr 49 2004-2005, p. 73). The following topics were covered in the 
Table 3 Platform companies in the sample and their characteristics

\begin{tabular}{llll}
\hline Platform & Online/local & Skill-level & Origin of company \\
\hline PI & Online & High & Norwegian \\
\hline P2 & Local & Low & Norwegian \\
\hline P3 & Local & Low & International \\
\hline P4 & Local & Low & International \\
\hline P5 & Local & Low & Norwegian \\
\hline P6 & Local and online & Low & Norwegian \\
\hline P7 & Online & High & International \\
\hline P8 & Local & Low & Norwegian \\
\hline P9 & Local & Low & International \\
\hline P10 & Local & High & Norwegian \\
\hline
\end{tabular}

interviews: the platform's business model, the characteristics of the platform workers, what characterizes the relationship between the platform companies and the workers, and how the platform companies approach issues related to working conditions.

The interviews were analysed in several rounds and with different coding and approaches, inspired by both induction and deduction. The first round of coding was thematic and based in the topics of the interview guide (Alsos et al. 2017). In the analysis, it became apparent that some companies adopt certain elements of the SER, in combination with characteristics of platform work. The typology of employment models therefore emerged from a more inductive approach. This will be elaborated in the findings section, first through a focus on the two 'exemplar' employment models, which are then supplemented with data from the other companies. After reading literature on precarious work, atypical work and the SER, the SOFL framework of Rubery et al. (2018) emerged as a useful tool for analysing the different employment models comparing with the SER. Through a more deductive approach, I was able to explore the limitations of this framework related to my data material. For instance, the SOFL framework does not highlight the characteristics of platform work as described by Stewart and Stanford (2017), and hence the characteristics of this type of work in the hybrid model became less visible. This is partly countered by highlighting the characteristics of platform work throughout the analysis. In addition, health and safety is paid relatively little attention in the SOFL framework, but emerges as quite important in platform work, as some of the platform companies mediate work that involves risks.

\section{Findings and analysis}

Platform companies are often described as a uniform phenomenon. However, the reality is quite different: platform companies appear considerably diverse in terms of their employment relationships and business models. In this section, the similarities and differences between platform companies and their employment models in Norway are explored through a case description of two platform companies - two opposites - that 
represent the variation in the data material. Roughly speaking, the sample of companies can be divided into two groups, and the case studies below serve as representative of the two employment models: the typical platform company (case P10) and the hybrid platform company (case P4). Thereafter, we compare the employment models with the SERs. The first employment model is referred to as the 'typical' platform company since it is the type of company most strongly associated with platform companies. The second employment model is referred to as the 'hybrid' platform company since it is a mix of the typical platform company and more traditional companies, but with atypical employment relationships.

\section{Two employment models}

\section{The typical platform company - case PIO}

Case P10 is a Norwegian company that mediates medium- to high-skilled work in a local labour market through a website. The company positions itself as an intermediary between customers and providers of work. It identifies with Uber, but operates within another industry. The providers of work are considered as self-employed by the company. The customers - individuals or companies - contact the firm through the website and receive an answer within 5 minutes. The concept is therefore described as on demand. The self-employed - referred to as consultants - have profiles with a considerable amount of information and data about themselves, including videos, CVs and ratings. This information is used in the distribution of work, to match the customers with the workers. The platform company conducts a 'screening' of the profile created by the consultant, followed by a more regular recruitment process. Uploading a profile is free, but when you are given a job, the platform company takes a cut. If a worker's rating is poor, that person might not be able to access new jobs on the platform. The company makes this assessment for each situation of low rating. The client customers are responsible for complying with the labour law and working time regulations. The platform company explains that, as an intermediary, it does not take this responsibility. The company does not invest in competence development either. When asked about this, the CEO answered,

'We do not. That would imply taking on an employer role, and as they are consultants, we cannot do that. The training they get is through guides, manuals etc. but it is up to the client company to provide the training they need. We have a lot of experienced people who do not need training'.

Many of those with profiles on the platform have a permanent position elsewhere but work through the platform as an additional job. Each worker sets his or her own wage. However, if a platform worker wants to secure an assignment, the hourly rate cannot be too high, but nor can it be too low, as the following quote illustrates.

'[Platform workers] set a minimum wage and the hourly rate they wish to be paid. Those who have a higher minimum wage get fewer requests for jobs'. 
In this way, the company makes sure that the transaction is relatively profitable for all parties.

\section{The hybrid platform company - case P4}

Case P4 is an international company with a local branch in Norway. The company matches customers with workers through an app. The work is repetitive and without specific skill requirements. The company perceives itself as an ordinary company that uses technology to 'optimize the process', and the company also describes itself as 'datadriven'. In contrast to the typical platform company, case P4 hires platform workers on marginal part-time contracts (fewer than 15 hours per week) with the option of working extra hours. The CEO describes why the company has chosen marginal part-time contracts as follows:

'We have chosen permanent employment contracts because it is an advantage to have employees. You have a clear responsibility, you may require certain things - that they appear at work, that they use certain equipment, that they follow our guidelines'.

Even though the platform workers are employed and the company provides certain equipment needed to do the job, the workers provide most of the equipment themselves. Workers are recruited through a more or less ordinary recruitment process, and then work is distributed through an app and with the aid of algorithms. A request is matched with a platform worker in the vicinity of the requested service. The platform worker receives an hourly payment, plus an additional payment for each assignment. The company does not have rating systems, but the platform workers are organized in teams with a team leader who helps to coach the workers. Since the company is 'data-driven' in the sense that it uses algorithms to match customers and workers, it has a good overview of the strengths and weaknesses of the workers. The company puts up rosters through the app about two weeks before the shifts, and the workers have the option to request certain days and hours. The platform workers are typically young students or migrants.

\section{Comparison of the two employment models}

The two exemplar employment models represent the typical and the hybrid platform company. The typical platform companies consider themselves an intermediary between customers and providers of labour or as a marketplace between different user groups, not as employers. The platform workers are solo self-employed. About half of the platform companies in the sample correspond to this model. The other half, the hybrid platform companies, either hire workers on marginal part-time contracts, or maintain a relatively stable relationship with their freelancers or the workers of a company they subcontract the work to. These companies have different arrangements for payment systems, health and safety and quality assurance; these resemble those of SERs, but they also have characteristics differentiating them from the standard employment model. Following the characteristics stressed by Stewart and Stanford (2017), both of these models differ from more traditional companies in terms of (1) varying working hours 
and work periods, (2) no furnishing of equipment needed to undertake the job, (3) no workplace provided by the company and (4) mediation of tasks by means of digital technology.

Table 4 summarizes the sample of platform companies, their relationship with the workers, the origin of the company and the employment model. Some of the platform companies in the sample also combine different employment relationships, and these are treated as hybrid platform companies in this article.

Table 4 Characteristics of the platform companies in the sample

\begin{tabular}{lllll}
\hline Platform & $\begin{array}{l}\text { Relations with } \\
\text { workers }\end{array}$ & $\begin{array}{l}\text { Origin of } \\
\text { company }\end{array}$ & $\begin{array}{l}\text { Employment } \\
\text { model }\end{array}$ & $\begin{array}{l}\text { Skill- } \\
\text { level }\end{array}$ \\
\hline PI & Freelancers & Norwegian & Hybrid & How \\
\hline P2 & Self-employed & Norwegian & Hybrid & Low \\
\hline P3 & Solo self-employed & International & Typical & Low \\
\hline P4 & Marginal part-time & International & Hybrid & Low \\
\hline P5 & Marginal part-time/ & Norwegian & Hybrid & Low \\
\hline P6 & subcontractors/freelancers & & High \\
\hline P7 & Solo self-employed & Norwegian & Typical & Low \\
\hline P8 & Solo self-employed & International & Typical & Low \\
\hline P9 & Subcontractor & Norwegian & Hybrid & High \\
\hline P10 & Solo self-employed & International & Typical & Typical \\
\hline
\end{tabular}

\section{Standard employment relationships and platform companies}

In the following, the employment models of the platform companies are assessed in light of the SER through SOFL framework (Rubery et al. 2018).

\section{Security}

The security dimension of the employment relationship requires stability of employment and income (in both work and nonwork periods), prospects of pay increase and access to social protection (Rubery et al. 2018). The typical and the hybrid employment model differ in these respects, as the latter gives access to some guaranteed wage income, where the typical platform company does not.

While the typical platform company relies on solo self-employed as a workforce, the platform workers in the hybrid platform companies are employees and have a guaranteed number of hours per week, open-ended contracts and access to social protections such as vacation pay, sick leave etc. The typical platform companies of which Uber is an ideal example - distribute tasks according to demand, and use data and algorithms to match customers' preferences and location (if locally based) 
with a service provider. One CEO said: 'We have no employees. We look for people who match our customers' requests'. (P7). The platform workers are self-employed persons who bear the risk of their own business. This follows the rhetoric of the platforms that they are intermediaries or marketplaces and not employers. Platform workers working via the typical platform company therefore have no guaranteed wage income, which, if they have no other job, might create substantial pressure on living standards.

Hybrid platform companies, on the other hand, use more traditional employment models, giving them more resemblance to companies using atypical working arrangements, as the following quote indicates:

'The part-time employees usually have some regular things to do, and it is up to them when they want to do them. They can say: 'I do it Monday or Tuesday', the regular things'. (P5)

Although the marginal part-timers receive some guaranteed income, Ilsøe et al. (2017) argue that marginal part-time work in fact results in a very low annual income and thus might lead to a precarious situation. This depends on whether this type of work represents an occasional source of income or if it is the main job. The platform workers in the hybrid platform companies often have the option of working extra hours, which leaves them in a situation very much like zero-hour contracts, which are described as a highly commodified and unpredictable employment form (Rubery \& Grimshaw 2016). In Norway, marginal part-timers have the opportunity to expand the number of hours in their contracts, which might give some additional guaranteed income. According to section $\ 14-3-1$ of the Working Environment Act, part-time employees who have regularly worked more than the hours stated in their contract over the previous 12 months are entitled to a contract equivalent to actual working hours.

When it comes to prospects of decent pay, there are differences in the possibilities of negotiating on pay for the typical and the hybrid platform companies. The platform worker in the typical platform company is paid per task, that is a form of piecework. The price is pre-determined by the platform company and the company takes a cut of the transaction. This gives the platform worker little opportunity to set the price of the service and it limits the possibility for negotiating the price, even though this is the norm for self-employed. The following quote illustrates this: 'We set the price. We decide the timing. Customers and providers can choose if they want to do it or not' (CEO, P2). Some platform workers seem to earn quite a lot and others very little, depending on the price and numbers of tasks completed as well as skills. In Norway, there is no statutory minimum wage and extended collective agreements do not cover the self-employed.

The payment model of the hybrid companies is traditional hourly pay, which provides workers with a more stable income than payment per assignment. Four of the platforms in our sample operate with hourly wages, and these are typically the companies also using marginal part-time contracts. Still, prices vary considerably according to the platform and the skill-level required to perform the job - from NOK 145 per hour (about 15 euros) to NOK 700 (about 72 euros), and the pay is unusually low for the platform companies mediating work without skill requirements. Platform workers on marginal part-time contracts might be covered by collective agreements or extended collective agreements as in the cleaning industry. 


\section{Opportunity}

In a SER, the employer provides training to ensure competence and career development. Lack of access to training may lead to workers not being able to progress, maintain their position or get a job elsewhere (Rubery \& Grimshaw 2016).

In general, competence development is limited for workers in both employment models, but even less so with the typical platform company. The main task of these companies, according to the CEOs, is to match demand and supply through a digital platform in the form of an app or a website. Competence development is therefore the responsibility of the platform workers themselves, as the following quote indicates.

'It is the consultants themselves who are responsible for the cost [of training]. There is no logical reason why we should pay for it. It is not about employer responsibility. Our business model is based on the consultants being responsible for their own development. We help by providing an extra sales channel for getting assignments'. (P7)

This is a platform mediating high-skilled work, and the platform workers are expected to improve their skills, but at their own expense and responsibility. In platform companies where the work is repetitive and without skill requirements, the training, if any, can consist of listening to a lecture on how the work is done, learning how to provide good service or clicking through an online course. 'They have tools they can click through, but it is all voluntary. Nothing is obligatory'. (P1). This usually takes about an hour.

The hybrid companies might provide some learning and skill development through projects of a similar type, but this is also minimal, and might be reserved for the most highly skilled. In fact, the complexity of the tasks and the skill level required to perform them seems to be more important for competence development than the employment model.

\section{Fair treatment}

The SER provides an institutional framework for having rights and the possibility of voicing issues at work. Without institutional systems that ensure the opportunity to voice concerns and safeguard fair treatment, workers might suffer from a fear of making complaints or of losing their job (Rubery et al. 2018).

In the platform companies, tasks are distributed through apps or a software system. Neither the hybrid nor the typical platform companies offer a workplace that can be a reference point for complaining about issues, discussing with colleagues or mobilizing on particular issues. However, this opportunity is more accessible for workers that can meet in a local labour market. Also, as the CEOs claim, the typical platform company is a marketplace in the sense that the platform workers, like other customers, have to call support when needing help with tasks.

The typical platform company also has rating systems that can lead to continuous fear of losing the job or additional tasks. When an assignment is performed, the customers have the opportunity to rate the service. The platform companies use these rating mechanisms to ensure quality. Poor ratings from customers can lead to a termination of the work relationship, without the platform workers having an opportunity to protest.

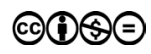


The following quote illustrates how the rating systems work as a form of quality assurance and control:

'Sometimes, if they [the platform workers] continue to get poor ratings, we may have to exclude them. This is stated in their contract'. (P3)

In other words, the platform workers might lose the possibility to access jobs if they receive poor ratings, and there are few institutional systems through which they can complain.

Due to competition law, self-employed platform workers do not have access to the same collective rights as platform workers in hybrid companies, including collective bargaining and the right to strike (Munkholm \& Schjøler 2018). Although the platform workers in the hybrid models have atypical working arrangements, they have the right to organize and to negotiate collective agreements. However, organizing and negotiating require either highly resourceful persons or platform workers that have a stake in the job (not only students) and, most likely, support from the trade union. At the time of the interviews, none of the platform companies had developed extensive frameworks for providing workers with a voice, but there are indications that collective negotiations are taking place in several platform companies in a Nordic context today (Jesnes et al. 2019).

\section{Life beyond work}

The SER safeguards life beyond work through regular hours and a clear division between work and nonwork time. An employer usually provides due notice of working hours and limits the use of on-call or overtime on days off, and especially during unsocial hours (Rubery \& Grimshaw 2016).

Both the typical and the hybrid platform companies have a narrative whereby this model provides flexibility to the workers, but they appear to remain silent on the possible risks of instability in payment. In order for platform workers to be entitled to payment, they must have been offered and accepted a specific assignment. Platform workers in typical platform companies might be logged onto the app or search for jobs without receiving either jobs or income. The transportation between, or to and from, missions is not paid, and this could be considered as unpaid labour. On many of the platforms, demand is higher during unsocial hours such as evenings, Saturdays and Sundays, and this is when the platform workers usually work.

The hybrid companies' provision of marginal part-time contracts implies that they to a certain extent recognize workers' need for security, as the quote below illustrates:

'Many want security, and we have chosen to offer this in the form of an employment contract. We want to provide both flexibility and stability. We also wanted to avoid the judicial grey zone, which often accompanies self-employment. It is easier to hire people, even though it implies certain costs'. (CEO, P4)

By using marginal part-time contracts, the hybrid platform companies ensure some division between work and nonwork periods. However, those that are dependent on the extra hours are also in a situation of waiting for new jobs and are therefore subject to employer demands for flexibility. 


\section{Risks of precarious work?}

Although the employment models of platform companies are associated with a high risk of precariousness, the workers are not necessarily in a precarious situation. The model indicates that the platform workers might be in a precarious situation if they are dependent upon this form of work. Table 5 summarizes the two employment models and how they differ from the SER.

Table 5 The employment models of platform companies and working conditions

\begin{tabular}{|c|c|c|c|}
\hline SOFL & SER & $\begin{array}{l}\text { Typical platform } \\
\text { companies }\end{array}$ & $\begin{array}{l}\text { Hybrid platform } \\
\text { companies }\end{array}$ \\
\hline \multirow[t]{4}{*}{ Security } & $\begin{array}{l}\text { Stability of } \\
\text { employment }\end{array}$ & Solo self-employed & $\begin{array}{l}\text { Open-ended contract (marginal } \\
\text { part-time) or relatively stable } \\
\text { freelance relationship }\end{array}$ \\
\hline & $\begin{array}{l}\text { Guaranteed } \\
\text { wage income }\end{array}$ & $\begin{array}{l}\text { No guaranteed hours. Depends } \\
\text { on demand and algorithmic } \\
\text { management }\end{array}$ & $\begin{array}{l}\text { Few guaranteed hours, possibility } \\
\text { of extra hours }\end{array}$ \\
\hline & Social security & $\begin{array}{l}\text { Not covered by Working Environ- } \\
\text { ment Act. Own responsibility. }\end{array}$ & $\begin{array}{l}\text { Covered by Working Environment } \\
\text { Act (except freelancers). Access to } \\
\text { social security measures (Table } 2 \text { ) }\end{array}$ \\
\hline & Decent pay & $\begin{array}{l}\text { Little opportunity for wage nego- } \\
\text { tiations. No legal minimum wage. } \\
\text { Extended collective agreements } \\
\text { do not cover self-employed. }\end{array}$ & $\begin{array}{l}\text { Little opportunity for wage } \\
\text { negotiations. Might be covered by } \\
\text { extended collective agreements. }\end{array}$ \\
\hline Opportunity & $\begin{array}{l}\text { Competence } \\
\text { development }\end{array}$ & $\begin{array}{l}\text { Low-/high-skilled work have more } \\
\text { bearing on competence develop- } \\
\text { ment than employment model. }\end{array}$ & $\begin{array}{l}\text { Low-/high-skilled work have more } \\
\text { bearing on competence develop- } \\
\text { ment than employment model. }\end{array}$ \\
\hline \multirow[t]{4}{*}{ Fair treatment } & $\begin{array}{l}\text { Institutional } \\
\text { framework }\end{array}$ & $\begin{array}{l}\text { Algorithmic management. No } \\
\text { workplace representation } \\
\text { mechanism. }\end{array}$ & $\begin{array}{l}\text { Algorithmic management. Work- } \\
\text { place representation mechanisms, } \\
\text { e.g. safety representative. }\end{array}$ \\
\hline & Workplace & $\begin{array}{l}\text { No workplace, which makes it } \\
\text { difficult to meet other platform } \\
\text { workers. }\end{array}$ & Not necessarily a workplace. \\
\hline & Job stability & $\begin{array}{l}\text { The rating systems might lead to } \\
\text { unfair dismissal or fear of such. }\end{array}$ & Not necessarily a rating system \\
\hline & Collective rights & $\begin{array}{l}\text { No right to strike or collective } \\
\text { bargaining. }\end{array}$ & Collective negotiations possible. \\
\hline $\begin{array}{l}\text { Life beyond } \\
\text { work }\end{array}$ & $\begin{array}{l}\text { Division between } \\
\text { work and non- } \\
\text { work time }\end{array}$ & $\begin{array}{l}\text { No prior notification of jobs. } \\
\text { Depends on demand. Risk of } \\
\text { unsocial hours. }\end{array}$ & $\begin{array}{l}\text { Some guaranteed hours, but still } \\
\text { subject to employer flexibility. Risk } \\
\text { of unsocial hours. }\end{array}$ \\
\hline
\end{tabular}

Platform companies - both employment models - differ from the SER in several ways that lead to a risk of precariousness. These include limited access to guaranteed wage income and social protection, lack of opportunities for career development and lack of access to institutional frameworks providing workers with collective rights. 
Platform workers reliant on this form of work are in a precarious situation. This might again depend on skill level and how attractive an individual is on the labour market. The differences between platform companies mediating high-skilled and low-skilled work and the consequences that skill-level has for working conditions are not well reflected through this data material and should be explored in further research.

Nevertheless, the precarious work risks are higher with the typical platform company than with the hybrid model. The typical platform company has been amply described in the existing literature and is characterized by its reliance on self-employed persons as a workforce and its use of data and algorithms in its management as a form of control. Hybrid platform companies are less explored in the existing literature on the platform economy. These companies have the characteristics of platform work as defined by Stewart and Stanford (2017): the use of atypical working arrangements with varying working hours and work periods, failure to provide the equipment needed to undertake the job, lack of a specific workplace and mediation of tasks by means of digital technology (i.e. apps or software systems). Still, they differ from the typical platform companies in the form of employment contract they use, with hybrid companies offering wider access to guaranteed wage income and social security. This illustrates that platform companies can achieve flexibility also by adopting certain elements from the SER; however, this might still put workers in a precarious situation.

\section{Why the hybrid employment model?}

Why do some platform companies choose a different employment model than the 'typical' one that relies on self-employment? Two main reasons are mentioned in the interviews: (1) the need for flexibility and stability in the workforce, and (2) regulations/ pressure from the trade unions and other regulating actors or legislation.

The need for flexibility and stability in the workforce is given as a reason for hiring people on marginal part-time contracts. This is in line with Atkinson's (1984) theory of the flexible firm, where companies seek a core workforce in addition to flexible workers. However, in the case of hybrid platform companies, the core workforce is reduced to a minimum and in the typical platform companies, it does not exist, and flexibility is what remains. The latter operate only with peripheral workers. This evokes the image of Srnicek (2017) of the typical platform companies as hyper-outsourced business models. At the same time, the hybrid platform companies do not seem to be in search of stability, but a sort of flexibility without risk. By having workers on marginal part-time contracts, the hybrid platform companies obtain the right to instruct the workers to use certain equipment and to follow the company's guidelines in certain periods with high demand, without compromising on the need for flexibility.

The second reason mentioned by the employers suggest that the institutional context is important for the choice of employment model. The CEOs mention pressure from regulators and social partners as a reason why they hire platform workers. This includes pressure from the legal framework, labour inspectorates and the unions. Hiring marginal part-timers seems to be an easy way to comply with regulations without having to respond to so much pressure from different actors.

This distinctive approach by platform companies in Norway towards a more traditional employment model, combined with the few examples of collective negotiations 
that do exist among platform companies and their respective social partners, might indicate that platform companies are gradually adopting elements of the Nordic labour market model such as more SERs with institutional frameworks for collective bargaining.

However, the part-time contracts offered by the hybrid companies are marginal and far from the norm for a permanent full-time contract. Marginal part-time contracts are also an atypical form of work associated with major precarious work gaps (Ilsøe et al. 2017). One might therefore consider, as suggested by Alberti et al. (2018), that hybrid platform companies represent yet another employment model driving precarization. The spread of both the typical and the hybrid model, together with other forms of atypical work, might have detrimental implications for the Nordic model of collective negotiations and bargaining in the affected industries.

\section{Conclusion}

This article provides a typology of the employment models of platform companies emerging in a Nordic context. The main difference between the employment models is that while the typical platform companies depend on labour from self-employed persons, the hybrid platform companies either hire workers on marginal part-time contracts or maintain a relatively stable relationship with their workforce. Both employment models differ from the SER and can lead to substantial precarious work gaps, as shown through the application of the SOFL framework (Rubery et al. 2018). However, the risks are higher for those working via the typical platform company. Hybrid platforms allow for wider access to guaranteed wage income, social security and other dimensions of the standard employment model. The employment model of hybrid platforms still differs substantially from the SER (Stewart \& Stanford 2017), and the work can be categorized as atypical. The employment strategy of the hybrid companies might be a way for companies to avoid regulatory problems while maintaining both flexibility and the possibility of instructing workers. If these two types of platform companies develop in a Nordic context, they might challenge the highly organized labour market, or at least the industries where they operate. This might further place workers in a precarious situation.

Why employers choose the hybrid model is an interesting question, both because it indicates that platform companies are not reliant on self-employed workers to conduct their business, and because it indicates that there are elements in the labour market that influence employment strategies. The institutional context seems to be the main reason for the Nordic platform companies' choice of not relying on self-employed workers. The data material suggests that platform companies experience pressure from regulators and social partners to comply with legislation, and this is partly why the hybrid platform company has developed. The development of hybrid platforms as a means for platforms to appease regulators and social partners is an important finding, which should have implications for the regulation of platforms also outside the Nordic countries.

This article points to some directions that future research should take. Further research on particular companies operating in different institutional contexts and industries might give support to the explanation provided in this article on how the institutional context has formed employment strategies. It might also shed light on whether the platform companies 'shop' elements of the Nordic labour market models to conduct business as usual without risking their reputation or to be sanctioned against by labour

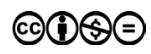


market actors. Future research should also explore other explanations, such as the differences in opportunities to regulate online and local platform work (Rasmussen 2018) and differences between industries (Bechter et al. 2012). Lastly, research is needed on the variations between platform companies mediating high-skilled compared to low-skilled work and how they differ with regard to working conditions, as this might be decisive for assessing the extent to which platform companies put workers in a precarious situation.

\section{Acknowledgements}

I am grateful to Beate Sletvold Øistad and Kristin Alsos (Fafo) for collaboration on data gathering and parts of the data analysis. I am also thankful to my PhD supervisors and colleagues for comments that greatly improved the article.

\section{References}

Alberti, G., Bessa, I., and Hardy, K., et al. (2018). In, against and beyond precarity: work in insecure times, Work, Employment and Society 32: 447-457. doi: https://doi. org/10.1177/0950017018762088.

Alsos, K., Jesnes, K., Øistad, B. S., and Nesheim, T. (2017). Når sjefen er en app. (When the boss is an app). Fafo-report 2017: 41.

Alsos, K. and Trygstad, S. C. (2018). Workplace democracy: Representation and participation gaps in the Norwegian labour market model. In Engelstad, F., Holst, C. \& Aakvaag, G. C. (eds.) Democratic State and Democratic. Institutional Change in the Nordic Model Society. De Gruyter. doi: https://doi.org/10.1515/9783110634082-012.

Altinn (2019). Frilanser. [Freelancer] https://www.altinn.no/starte-og-drive/starte/foroppstart/frilanser/ Updated January 24, 2019.

Andersen S. K., Dølvik J. E., and Ibsen C. L. (2014). Nordic labour market models in open markets. European Trade Union Institute. Report nr. 132.

Atkinson, J. (1984). Manpower Strategies for Flexible Organisations. Personnel Management, 16, 28-31.

Bechter B., Brandl B., and Meardi G. (2012). Sectors or countries? Typologies and levels of analysis in comparative industrial relations, European Journal of Industrial Relations 18(3): 185-202. doi: https://doi.org/10.1177/0959680112452691.

Berg J. (2016). Income Security in the On-demand Economy: Findings and Policy Lessons from a Survey of Crowdworkers. ILO.

Codagnone, C., Biagi, F. and Abadie, F. (2016). The Passions and the Interests: Unpacking the 'Sharing Economy'. Institute for Prospective Technological Studies, JRC Science for Policy Report. doi: https://doi.org/10.2791/474555.

De Stefano, V. (2016). The Rise of the 'just-in-time workforce': on-demand work, crowdwork and labour protection in the 'gig-economy', Comparative Labor Law \& Policy Journal. Bocconi Legal Studies Research Paper No. 2682602. doi: https://doi.org/10.2139/ ssrn.2682602.

De Stefano, V., and Aloisi, A. (2018). Fundamental Labour Rights, Platform Work and Human-Rights Protection of Non-Standard Workers Forthcoming, Labour, Business and Human Rights Law, Edited by Janice R. Bellace and Beryl ter Haar, Edward Elgar Publishing Ltd.; Bocconi Legal Studies Research Paper No. 3125866. doi: https://doi. org/10.2139/ssrn.3125866. 
Dølvik, J. E., and Jesnes, K. (2017). Nordic labour markets and the sharing economy - report from a pilot project, TemaNord 2017: 508. doi: https://doi.org/10.6027/tn2017-508.

Eurofound. (2017) In-work Poverty in Europe, Luxembourg: Publications Office of the European Union.

Ferner, A. (1997). Country of origin effects and HRM in multinational companies, Human Resource Management Journal 7 (1): 19-37. doi: https://doi.org/10.1111/j.1748-8583.1997. tb00271.x.

Hotvedt, M. J. (2019). Legislative Framework: Key Challenges in the Nordic Context, Presentation at the Conference on the Future of Work, April 4-5, 2019, Reykjavik, Iceland.

Hotvedt, M. J. (2018a). The contract-of-employment test renewed. A Scandinavian approach to platform work, Spanish Labour Law and Employment Relations Journal 7 (1-2): 56-74. doi: https://doi.org/10.20318/sllerj.2018.4436.

Hotvedt, M. J. (2018b). Arbeidstaker - quo vadis? Den nyere utviklingen av arbeidstakerbegrepet. [Employee - quo vadis? The recent developments in the concept of an employee], Tidsskrift for Rettsvitenskap 131 (01): 42-103. doi: https://doi.org/10.18261/issn.15043096-2018-01-02.

Hotvedt, M. J. (2016). Arbeidsgiveransvar i formidlingsøkonomien? Tilfellet Uber. [Employer responsibility in the intermediation economy? The case of Uber], Lov og rett 55(8). doi: https://doi.org/10.18261/issn.1504-3061-2016-08-03.

Howcroft, D., and Bergvall-Kåreborn, B. (2018). A typology of crowdwork platforms, Work, Employment and Society. Work, Employment and Society, 33(1): 21-38. doi: https://doi. org/10.1177/0950017018760136.

Ilsøe, A., Larsen, T. P., and Felbo-Kolding, J. (2017). Living hours under pressure: flexibility loopholes in the Danish IR-model, Employee Relations 39: 888-902. doi: https://doi. org/10.1108/er-03-2017-0049.

Ilsøe, A., and Madsen, L. (2017). Digitalisering af arbejdsmarkedet: Danskernes erfaring med digital automatisering og digitale platforme. Faos.

Jesnes, K., Ilsøe, A., and Hotvedt, M. J. (2019). Collective agreements for platform workers? Examples from the Nordic countries, Nordic Future of Work Brief 3. Fafo. Oslo.

Kässi, O., and Lehdonvirta, V. (2016). Online Labour Index: Measuring the Online Gig Economy for Policy and Research, Paper presented at Internet, Politics \& Policy 2016, September 22-23, Oxford, UK. http://ilabour.oii.ox.ac.uk/online-labour-index/.

Lee, M. K., Kusbit, D., Metsky, E., and Dabbish, L. (2015). Working with Machines: The Impact of Algotithmic and Data-Driven Management of Human Workers, Conference Paper published 2015 in Proceedings of the 33rd Annual ACM Conference on Human Factors in Computing Systems - CHI '15. doi: https://doi.org/10.1145/2702123.2702548.

London Employment Tribunal. (2016). Y. Aslam, J. Farrar and others v. Uber. Case no: $2202551 / 2015$.

Moore, S., and Newsome, K. (2018). Paying for free delivery: dependent self-employment as a measure of precarity in parcel delivery, Work, Employment and Society 32: 475-492. doi: https://doi.org/10.1177/0950017018755664.

Munkholm, N. V., \& Schjøler, C. H. (2018). Platform work and the Danish model - legal perspectives, Nordic Journal of Commercial Law, 2018 (1). doi: https://doi.org/10.5278/ ojs.njcl.v0i1.2487.

Nergaard, K., and Øistad, B. S. (2016). Fastsettelse av lønn og honorarer for kortidsoppdrag på det kunstneriske feltet. En utredning for Rådet for folkemusikk og folkedans. [Determination of salary and fees for short-term assignments in the artistic field. An investigation for the Council of Folk Music and Folk Dance]. Fafo-paper 2016: 19.

Official Statistics of Finland. (2017). Labour Force Survey. Platform Jobs 2017, Helsinki: Statistics Finland. http://www.stat.fi/til/tyti/2017/14. [Accessed November 28, 2018]. 
Oppegaard, S. M. N. (2018). The Strains of Luxury. Labor in the Platform Economy. The Case of Uber Black in Oslo. Master's thesis, Sociology. Oslo: University of Oslo.

Ot.prp. 49, (2004-2005). Om lov om arbeidsmiljø, arbeidstid og stillingsvern mv. (arbeidsmiljøloven). [About the law on working environment, working hours and employment protection etc. (Working Environment Act)] https://www.regjeringen.no/no/dokumenter/ otprp-nr-49-2004-2005-/id396602/sec1.

Pesole, A., Brancati, U., Fernández-Macías, E., Biagi, F., and González Vázquez, I. (2018). Platform Workers in Europe. EUR29275 EN, Luxembourg: Publications Office of the European Union. doi: https://doi.org/10.2760/742789.

Pongratz, H. J. (2018). Of crowds and talents: discursive constructions of global online labour, New Technology, Work and Employment 33: 58-73. doi: https://oi.org/10.1111/ ntwe.12104.

Prassl, J. (2018). Humans as a Service - The Promise and Perils of Work in the Gig Economy, London: Oxford University Press. doi: https://doi.org/10.1093/oso/97801987 97012.001.0001.

Rasmussen, S. (2018). Platform Work in Denmark and Regulatory Issues: Towards a Conceptualization. Presentation at Nordic Work Life Conference, June 2018, Oslo.

Rubery, J., and Grimshaw, D. (2016). Precarious work and the commodification of the employment relationship: the case of zero hours in the UK and mini jobs in Germany. Den Arbeitsmarkt verstehen, um ihn zu gestalten. Springer VS, Wiesbaden, 2016. 239-254. doi: https://doi.org/10.1007/978-3-658-12159-4 19 .

Rubery J., Grimshaw D., Keizer A., and Johnson, M. (2018). Challenges and contradictions in the 'normalising' of precarious work, Work, Employment and Society 32(3): 509-527. doi: https://doi.org/10.1177/0950017017751790.

SOU. (2017: 24). Ett arbeidsliv i förändring - hur påverkas ansvaret för arbetsmiljøn [A changing working life - how is the responsibility for the working environment affected?]

Srnicek, N. (2017). Platform Capitalism, John Wiley \& Sons.

Stewart, A., and Stanford, J. (2017). Regulating Work in the Gig Economy: What are the Options? The Economic and Labour Relations Review 28(3): 420-437. doi: https://doi. org/10.1177/1035304617722461.

Svalund, J., Peixoto, A., Dølvik, J. E., and Jesnes, K. (2018). Hiring of flexible and fixed-term workers in five Norwegian and Swedish industries, Nordic Journal of Working Life Studies, (8): 3. doi: https://doi.org/10.18291/njwls.v8i3.109540.

Visser, J. (2009). The quality of industrial relations and the Lisbon Strategy. In: Industrial Relations in Europe 2008, Luxembourg: European Commission 45-73.

Wood, A. J., Graham, M., Lehdonvirta, V., and Hjorth, I. (2018). Good gig, bad big: autonomy and algorithmic control in the global gig economy, Work, Employment and Society, 33(1): 56-75. doi: https://doi.org/10.1177/0950017018785616. 